\title{
Long-Term Disease Control with Lapatinib and Capecitabine in a Heavily Pretreated Patient with ErbB2-Positive Metastatic Breast Cancer
}

\author{
Tina Idris Peter Krippl Uwe Lang Edgar Petru \\ Universitätsklinik für Frauenheilkunde und Geburtshilfe, Graz, Österreich
}

\section{Key Words}

Breast cancer - Palliative chemotherapy - Lapatinib .

Capecitabine $\cdot$ ErbB2-positivity $\cdot$ Her2-positivity

\section{Summary}

Background: The optimal sequence of systemic palliative chemotherapy in metastatic breast cancer is unknown. Case Report: We report the course of disease in a patient aged 24 years at the onset of disease, who was treated over 17 years for her metastatic ErbB2-positive breast cancer. Seventeen years ago, the patient was diagnosed to have invasive ductal breast cancer and underwent surgical treatment. She received 6 cycles of adjuvant chemotherapy with CMF (cyclophosphamide, methotrexate, 5-fluorouracil). Twenty-eight months after the primary surgery, the patient developed a histologically verified lung metastasis, and subsequently received 8 different lines of chemotherapy, including high-dose cytotoxic therapy and stem cell support as well as trastuzumab. In addition, she received 5 different types of antihormonal treatment. Due to the recent progression of her lung metastasis, 27 cycles of lapatinib and capecitabine were administered. A long-term partial response in the lung was observed. Conclusions: Individualized systemic treatment with the tyrosine kinase inhibitor lapatinib and capecitabine in heavily pretreated patients with Her2-positive metastatic breast cancer may lead to effective palliation for almost 2 years despite extensive pretreatment.

\section{Schlüsselwörter \\ Brustkrebs - Palliative Chemotherapie - Lapatinib . Capecitabin · ErbB2-Positivität · Her2-Positivität}

\section{Zusammenfassung}

Hintergrund: Die optimale Abfolge palliativer Chemotherapien bei metastasiertem Brustkrebs ist nicht bekannt. Fallbericht: Wir berichten den Fall einer zum Zeitpunkt der Diagnosestellung 24-jährigen Patientin, die 17 Jahre lang wegen ihrer ErbB2-positiven metastasierten Brustkrebserkrankung behandelt wurde. Vor 17 Jahren wurde bei der Patientin ein invasiv duktales Mammakarzinom diagnostiziert. Sie wurde chirurgisch behandelt und erhielt 6 Zyklen einer adjuvanten Chemotherapie mit CMF (Cyclophosphamid, Methotrexat, 5-Fluorouracil). Achtundzwanzig Monate postoperativ entwickelte die Patientin eine histologisch verifizierte Lungenmetastase und erhielt im Anschluss daran 8 verschiedene Formen einer Chemotherapie, inklusive Hochdosistherapie und Stammzellgabe sowie Trastuzumab. Zusätzlich wurden 5 verschiedene Formen einer antihormonellen Therapie verabreicht. Nachdem die Patientin erneut pulmonal eine Progression aufwies, wurden 27 Zyklen einer Kombination von Lapatinib und Capecitabin verabreicht, unter der eine partielle Tumorremission erreicht werden konnte. Schlussfolgerungen: Auch bei jahrzehntelang vortherapierten Patientinnen ist es möglich, mit dem Tyrosinkinase-Inhibitor Lapatinib und Capecitabin ein Ansprechen für beinahe zwei Jahre zu erzielen.

\section{KARGER}

Fax +497614520714

Information@Karger.de

www.karger.com (c) 2010 S. Karger GmbH, Freiburg
Dr. Tina Idris

Universitätsklinik für Frauenheilkunde und Geburtshilfe

Auenbruggerplatz 14, 8036 Graz, Österreich

Tel. +43316 385-80828, Fax -14197

tina.idris@gmx.at 


\section{Introduction}

The optimal treatment sequence in patients with Her2-positive metastatic breast cancer is unknown. We report the favorable course of disease in such a patient.

\section{Case Report}

A 24-year-old patient was diagnosed with invasive breast cancer and underwent surgical treatment in March 1992 (table 1). Twenty-eight months after the primary surgery, she developed a histologically verified lung metastasis. She received various forms of chemotherapy for recurrent progressive disease including anthracyclines, taxanes, high-dose chemotherapy and stem cell support, nitrosoureas, platinum agents, oxazaphosphorines, antimetabolites, vinca alkaloids, and the monoclonal antibody trastuzumab. In addition, after stabilization during chemotherapy, various antihormonal treatments were given. After 181 months, the disease again progressed in the lung which was confirmed by computed tomography using the RECIST criteria. At that time, the patient only had minor pulmonary symptoms and a Karnofsky performance score of 90. The patient received lapatinib and capecitabine within the international LEAP study. Lapatinib acts as a dual tyrosine kinase inhibitor at both the extracellular and the intracellular level of Her2-positive tumor cells. In addition, the Her1 receptor is blocked. Twenty-seven cycles of lapatinib and capecitabine produced a long-term partial response in the lung which was again confirmed by computed tomography using the RECIST criteria. During therapy, the patient only experienced modest palmoplantar erythrodysesthesia (hand-foot syndrome) and no signs of myelosuppression. The dose of capecitabine had to be reduced twice due to grade 2 hand-foot syndrome $2,000 \mathrm{mg} / \mathrm{m}^{2} /$ day initially to $1,058 \mathrm{mg} / \mathrm{m}^{2} /$ day. The dose of lapatinib was maintained at its original level $(1,250 \mathrm{mg}$ daily). Twenty months after initiation of treatment with lapatinib and capecitabine, computed tomography using RECIST criteria again revealed tumor progression in the lung associated with enlarged diaphragmatic lymph nodes.

Table 1. Course of disease in a patient aged 24 years at the onset of disease, who was treated over 17 years for her metastatic breast cancer

\begin{tabular}{|c|c|c|c|}
\hline $\begin{array}{l}\text { Time, } \\
\text { months }\end{array}$ & Clinical event & Therapy, clinical consequence & Remarks \\
\hline 0 & $\begin{array}{l}\text { right breast cancer pT1c, G3, negative axillary lymph } \\
\text { nodes, ER+ (score 1/12), PR+ (score 6/12) }\end{array}$ & $\begin{array}{l}\text { right mastectomy and axillary } \\
\text { dissection }\end{array}$ & $\begin{array}{l}\text { Her2 status was determined on primary } \\
\text { tumor } 8 \text { years after diagnosis }\end{array}$ \\
\hline $1-5$ & adjuvant chemotherapy & 6 cycles $\mathrm{CMF}$ & \\
\hline 28 & multiple lung metastases, maximum size $11 \mathrm{~mm}$ & & histological verification $(\mathrm{ER}+, \mathrm{PR}+)$ \\
\hline $28-34$ & & 6 cycles epirubicin + paclitaxel & partial remission \\
\hline $35-38$ & multiple lung metastases, maximum size $5 \mathrm{~mm}$ & $\begin{array}{l}\text { stem cell transplantation, high- } \\
\text { dose chemotherapy with BCNU, } \\
\text { carboplatin + cyclophosphamide }\end{array}$ & remission \\
\hline $39-50$ & & observation & \\
\hline $50-55$ & progression of lung metastases, maximum size $1.8 \mathrm{~cm}$ & 4 cycles cisplatinum + ifosfamide & \\
\hline $56-57$ & partial remission of lung metastases, maximum size $0.7 \mathrm{~cm}$ & tamoxifen & \\
\hline 58 & progression of lung metastases, maximum size $1.2 \mathrm{~cm}$ & GnRH + letrozole & best response: stable disease \\
\hline 74-79 & progression of lung metastases, maximum size $1.4 \mathrm{~cm}$ & 3 cycles docetaxel + cisplatin & best response: stable disease \\
\hline 80-94 & stabilization of lung metastases, maximum size $1.1 \mathrm{~cm}$ & toremifen & best response: stable disease \\
\hline $95-101$ & progression of lung metastases, maximum size $1.5 \mathrm{~cm}$ & $\begin{array}{l}\text { trastuzumab }+ \text { capecitabine } \\
\text { (6 cycles) }\end{array}$ & \\
\hline 102-107 & stabilization of lung metastases, maximum size $0.9 \mathrm{~cm}$ & medroxyprogesterone acetate & extensive weight gain \\
\hline $108-131$ & stabilization of lung metastases, maximum size $1.0 \mathrm{~cm}$ & goserelin + exemestane & \\
\hline $131-136$ & progression of lung metastases, maximum size $1.7 \mathrm{~cm}$ & $\begin{array}{l}\text { gemcitabine + vinorelbine } \\
\text { ( } 6 \text { cycles })\end{array}$ & $\begin{array}{l}\text { best response: disease regression } \\
\text { (lung metastases up to } 1 \mathrm{~cm} \text { ) }\end{array}$ \\
\hline $137-149$ & progression of lung metastases, maximum size $2.0 \mathrm{~cm}$ & vinorelbine ( 12 cycles) & disease regression \\
\hline 154 & progression of lung metastases, maximum size $2.5 \mathrm{~cm}$ & $\begin{array}{l}\text { right pleurectomy, resection of } \\
\text { multiple lung metastases }\end{array}$ & $\begin{array}{l}\text { histological confirmation of metastases } \\
\text { (receptor status: } \mathrm{ER}+, \mathrm{PR}+, \mathrm{Her} 2+\end{array}$ \\
\hline 155 & & $\begin{array}{l}\text { postoperative PEG-liposomal } \\
\text { doxorubicin, mitomycin C, vinorel- } \\
\text { bine + trastuzumab ( } 6 \text { months) }\end{array}$ & best response: stable disease \\
\hline 180 & progression of 3 lung metastases, maximum size $4.6 \mathrm{~cm}$ & & \\
\hline 180-201 & & $\begin{array}{l}\text { capecitabine } 2,000 \mathrm{mg} / \mathrm{m}^{2} / \text { day days } \\
1-14+\text { lapatinib } 1,250 \mathrm{mg} / \text { day days } \\
1-21 \text { ( } 27 \text { cycles })\end{array}$ & $\begin{array}{l}\text { partial response of lung metastases, } \\
\text { maximum size of metastases } 2.2 \mathrm{~cm} \\
\text { confirmed by CT and RECIST criteria }\end{array}$ \\
\hline present & progression of lung metastases & & \\
\hline
\end{tabular}




\section{Discussion}

We describe the favorable course of disease in a patient with Her2-positive metastatic breast cancer heavily pretreated over a period of 15 years. Our patient experienced a partial response with lapatinib and capecitabine that lasted for 20 months. A phase III, randomized, open-label study showed that lapatinib plus capecitabine is an active combination in women with Her2-positive metastatic breast cancer previously exposed to anthracyclines, taxanes, and trastuzumab. Lapatinib plus capecitabine have been found significantly more effective than capecitabine alone; the median time to progression was 8.4 months in the combination therapy arm as compared to 4.4 months in the monotherapy arm [1].

Our patient experienced a partial tumor remission during lapatinib and capecitabine lasting for almost 2 years; an exploratory analysis of the pivotal phase III study of lapatinib and capecitabine showed that patients with fewer prior cytotoxic regimens and only 1 prior trastuzumab regimen benefited more from lapatinib and capecitabine than those with multiple lines of previous therapy. Patients with $<3$ prior regimens on lapatinib and capecitabine had a $63 \%$ reduction in the risk of progression whereas patients with $>3$ regimens only had a $41 \%$ reduction in the risk of progression [2].

Despite the significant reduction of the capecitabine dose due to palmoplantar erythrodysesthesia, the response in our patient was durable while maintaining the dose of lapatinib at the original level. After adapting the dose of capecitabine, treatment was well tolerated over months. In particular, the low toxicity of the regimen administered for allowed the patient to continue her work as a city councilor of a small town. She greatly appreciated the lack of myelosuppression.

There are several treatment options for patients with metastatic Her2-positive breast cancer. The first is trastuzumab in combination with alternative chemotherapy, the second lapatinib and capecitabine as used in our patient. In addition, aromatase inhibitors can be combined with either trastuzumab or lapatinib. The chemotherapy-free combination of trastuzumab and lapatinib may also be chosen. A bevacizumab-based regimen may also represent a valuable treatment option.

\section{Conclusion}

We conclude that lapatinib and capecitabine may be of potential value even in heavily pretreated selected women with Her2-positive metastatic breast cancer. This regimen may lead to long-term palliation in such patients.

\section{Conflict of Interest}

E. Petru has received honoraria for the participation in advisory boards and presentations from Glaxo Smith Kline and Roche. All other authors have no conflicts of interest to disclose.

\section{References}

Geyer CE, Forster J, Lindquist D, Chan S, Romieu CG, Pienkowski T, Jagiello-Gruszfeld A, Crown J, Chan A, Kaufman B, Skarlos D, Campone M, Davidson N, Berger M, Oliva C, Rubin SD, Stein $\mathrm{S}$, Cameron D: Lapatinib plus capecitabine for Her2-positive advanced breast cancer. NEJM 2006;355:2733-2743.
Crown J, Casey MA, Cameron D, et al.: Lapatinib plus capecitabine in Her2-positive metastatic breast cancer: exploratory analyses by prior therapy. Breast Cancer Res Treat 2009;113: 207-209. 